Revue Française de Civilisation Britannique

\title{
Review of British Broadcasting and the Public- Private Dichotomy by Simon Dawes
}

Lucie de Carvalho

\section{OpenEdition}

\section{Journals}

Electronic version

URL: http://journals.openedition.org/rfcb/5082

DOI: $10.4000 /$ rfcb.5082

ISSN: 2429-4373

Publisher

CRECIB - Centre de recherche et d'études en civilisation britannique

Electronic reference

Lucie de Carvalho, « Review of British Broadcasting and the Public-Private Dichotomy by Simon Dawes », Revue Française de Civilisation Britannique [Online], XXIV-4 | 2019, Online since 22 November 2019, connection on 27 November 2019. URL : http://journals.openedition.org/rfcb/5082 ; DOI : $10.4000 / \mathrm{rfcb} .5082$

This text was automatically generated on 27 November 2019.

\section{(†)

Revue française de civilisation britannique est mis à disposition selon les termes de la licence Creative Commons Attribution - Pas d'Utilisation Commerciale - Pas de Modification 4.0 International. 


\title{
Review of British Broadcasting and the Public-Private Dichotomy by Simon Dawes
}

\author{
Lucie de Carvalho
}

\section{REFERENCES}

Simon Dawes, British Broadcasting and the Public-Private Dichotomy: Neoliberalism, Citizenship and the Public Sphere, London, Palgrave Macmillan, 2017.

1 The private-public dichotomy has been an object of intense scholarly scrutiny over the past fifty years, especially since the structural changes triggered by the expansion of neoliberal reforms in the 1980s. While a fair amount of research has been conducted on this question in fields such as political science and social sciences, studies in political philosophy have been scarcer. British Broadcasting and the Public-Private Dichotomy partakes in this enduring conceptual debate and questions its methodological relevance by applying it to the British broadcasting sector. This book is intended for anyone interested in regulation and the tensions around the permeable and elusive boundary between what is sometimes narrowly described as the "public v. the private sector' binary. Understanding the stakes of broadcasting regulation means questioning not only the social, political and economic functions of the state and of broadcasting actors, but also their relationship to the public. Using the role of the state and of its relations with the private sector as the broader analytical window is indeed fundamental in so far as, as the author puts it, 'the mass media communications sector lies in both the role it plays in organising the symbolic world [...] and in its link between the economic structures and cultural formations of modern capitalist societies.' (p. 70).

2 Simon Dawes takes a rather original approach, by elaborating on the genealogical perspective framed by Michel Foucault in order to engage with theoretical and 
methodological debates in media studies. The aim is to grasp the discursive dynamics of power and control at work behind broadcasting regulation. In other words, Dawes's work partakes in the ongoing reappraisal of the importance of Michel Foucault's criticism of neoliberal power and knowledge structures which is currently taking place in the English-speaking academic world (the Anglo-Foucauldians).

Drawing on this perspective, the author discusses and assesses the relevance of the theoretical and methodological concepts that have traditionally been used in academic research to analyse broadcasting regulation: 'public service', 'citizenship', and 'public sphere'. Like a set of Russian dolls, these fundamental conceptual viewpoints are then articulated with those of political participation, consumerism, choice, and competition, which help delineate 'public control'. Since the study of broadcasting cuts across a number of academic lines, Dawes navigates around and draws on several and complementary intellectual traditions ranging from political philosophy (Kant, Hegel, Foucault, for example) to sociology (Habermas, Marshall, Williams, among others) or critical discourse analysis (Mouffe, for instance).

The book offers one of the most up-to-date and comprehensive literature reviews of major scholars' works on broadcasting, starting with the key notion of 'public' as both a noun ('the public') and a modifier ('public interest', 'public sector'). The author aims to 'problematise' the 'public' as an analytical object, in order to investigate the complexity that lurks behind such seemingly transparent concepts. More specifically, the analysis takes on the almost hackneyed concept of 'public sphere' coined by Habermas in order to reveal its weaknesses and the way in which it became a tool for scholars to buttress their take on broadcasting regulation. Similarly, Dawes does not only define these concepts or show that they are far from being 'vague notions' (p. 90), he tackles their inherent ambiguities meticulously, and the ways they have been construed, championed, challenged, contested, discarded, or reappraised by scholars. The notion of 'critique' in the intellectual sense really is the cornerstone of Dawes's research.

Yet, his fundamental interest is not only to take stock of the theoretical debates which have been raging since the 1980 s, but also to articulate a political statement, by advocating for a reappraisal of the UK policies on media regulation using this Foucauldian perspective.

6 Moreover, this book makes a most impressive contribution to the ever-evolving literature on neoliberalism. In an attempt to somehow 'depoliticise' or 'de-reify' this concept, Dawes indeed demonstrates that neoliberalism should neither be dismissed swiftly nor used as a monolithic framework, and that it cannot be boiled down to simplistic oppositions, be they between the state and markets or between citizens and consumers. On the contrary, it needs to be approached and deconstructed as an essentially protean discursive process, 'neoliberalisation'. What this book attempts to capture are the fundamental tensions between the collective and the individual. Analysing broadcasting regulation opens inroads into the intricacies of free speech and the freedom of the press, on which all pluralist and deliberative democracies should rest.

7 As regards structure, the book is divided into four somewhat unbalanced parts. The Foucauldian non-chronological approach is defined and the need for a general rethinking of the broadcasting theoretical traditions is justified in the first part (chapters 1 and 2). 
8 In Part Two, Dawes not only offers a critical overview of Habermas's seminal public sphere theory and of its limitations, he also traces its historical roots back in time (chapter 3). Chapter 4 and chapter 5 explore how citizenship, consumption, and neoliberalism have been used - or misused - in recent broadcasting literature. By addressing the divide between politics and economics, these chapters help grasp the elusive and ever-shifting figure of the consumers and citizens. They interrogate the limits of T.S. Marshall's citizenship theory in the sense that it has undermined the scope of citizens' political participation (Chapter 4), and demonstrate how the concepts of citizenship and consumption have been construed in broadcasting discourses and thus need to be transcended. Finally, Dawes successfully anchors this critical discussion of the consumer-citizen binary in a detailed overview of recent literature on neoliberalism, praising the analytical interest of the Anglo-Foucauldian governmentality approach, which enables scholars to historicise this key object of study. Neoliberalism thus becomes an instrument of power and active component of public policy (Chapter 5).

9 Once this preliminary definitional work is done, Dawes then tackles how the above concepts have shaped scholarly debates on broadcasting regulation in the UK (Part Three) and focusses on the problematisation of the rationale underpinning them. Chapter 6 addresses the 'public control v. private enterprise' dichotomy, thus furthering the book's exploration of what the phrases 'public interest' and 'public value' have actually entailed. Chapter 7 takes a rather different take on regulation by focussing on the way policymakers' discourses have constructed the rise of 'consumer sovereignty', which has in turn been alternatively politicised and depoliticised. Finally, Dawes shifts his standpoint by questioning the interest of the concept of monopoly as a defining parameter to characterise public services, especially given that competition has gained political and intellectual credence since the neoliberal turn of the 1980 s.

In Part Four, the author really hits the heart of his research project: the public - private dichotomy, as the book takes a more decisively prescriptive turn to provide new impetus for future research on public media models. The intellectual value of neoliberalism and citizenship as key concepts is first advocated (chapter 8). A similar direction is defended in the following chapter, which encourages future scholars to transcend the traditional opposition between social and political citizenship, in order to embrace less exclusive analytical categories. By looking at political participation and the process of individualisation, Chapter 10 also calls for moving beyond the 'activepassive', 'citizen-consumer' binary. It promotes the use of an alternative conceptual tool, 'the voice'. The voice is defined as a process to pin down the way neoliberalism has reshaped the very concept of citizenship and the spaces conducive to claiming new rights or defending sometimes contradictory interests. The last binary to be reassessed is the bidimensional state v. market nexus (Chapter 11). Yet, Dawes advocates for retaining the private-public binary, provided that the general reappraisal of the concepts of citizens and the public sphere and the reconfiguration of 'neoliberalisation' as a process he outlined in the previous chapters be taken on board.

11 Through this far-reaching and thorough exploration of theoretical debates, Dawes successfully helps his readers navigate an intricate conceptual and methodological ecosystem. Here, the author has built a solid case in favour of Foucault's genealogical perspective without shying away from addressing and answering its detractors. 
12 Yet, the extreme wealth of the theoretical apparatus demonstrated also gives rise to the three major limits of the book. Firstly, and conversely to what the title could suggest, this book is not a political or sociological analysis of public-private tensions in a specific case study. Therefore, this book is not necessarily suited for readers looking for a historical narrative of the evolution of the UK broadcasting sector, which actually takes a back seat throughout the whole book. Moreover, in his ambitious attempt to provide a most comprehensive and detailed account of the relevant scholarly debates, the author somehow fails to make his own voice clearly heard, except in the last three chapters. Finally, the conceptual complexity of this historiographical work means that readers will most likely need to be well versed in Foucault's work and in media study theories to fully grasp Dawes's demonstration.

This being said, Simon Dawes's book is a fundamentally original, rich, and impressive genealogical work, which provides precious insight in a fifty-year intellectual history of broadcasting regulation in the UK. Between its lines emerges a rare, intellectuallydaring, and historicised definition of the British broadcasting culture.

\section{AUTHORS}

\section{LUCIE DE CARVALHO}

Maître de conférence en civilisation britannique, Université de Lille, CECILLE 